TWO REVOLUTIONS 



\section{TWO REVOLUTIONS}

\section{Village Reconstruction and the Cooperative \\ Movement in Northern Shaanxi, \\ 1934-1945}

PAULINE B. KEATING

STANFORD UNIVERSITY PRESS

STANFORD, CALIFORNIA

1997 
Stanford University Press

Stanford, California

(C) 1997 by the Board of Trustees of the Leland Stanford Junior University

Printed in the United States of America

CIP data are at the end of the book 